\title{
INSULIN RESISTANCE IN OBESE ADOLESCENTS AND ADULT MEN MODIFIES THE EXPRESSION OF PROLIFERATION RELATED GENES
}

\author{
O. H. MINCHENKO ${ }^{1 \bowtie}, Y$. M. VILETSKA ${ }^{1}$, D. O. MINCHENKO ${ }^{1,2}$, V. V. DAVYDOV 3 \\ ${ }^{1}$ Palladin Institute of Biochemistry, National Academy of Sciences of Ukraine, Kyiv; \\ ๒e-mail: ominchenko@yahoo.com; \\ ${ }^{2}$ Bohomolets National Medical University, Kyiv, Ukraine \\ ${ }^{3} \mathrm{SI}$ "Institute of Children and Adolescent Health Care, \\ National Academy of Medical Sciences of Ukraine”, Kharkiv
}

Received: 11 December 2018; Accepted: 14 March 2019

Numerous data demonstrate that key regulatory factors, enzymes and receptors including HSPA5, MEST, SLC1A3, PDGFC, and ADM represent poly-functional, endoplasmic reticulum stress-dependent proteins, which control variable metabolic pathways. The expression level of genes of these proteins in the blood and subcutaneous adipose tissue of obese adolescents and adult men with and without insulin resistance was studied. It was shown that in blood of obese adolescents without insulin resistance the expression level of SLC1A3, HSPA5, MEST, and PDGFC genes was significantly increased, but development of insulin resistance led to down-regulation of these genes expression except HSPA5 gene as compared to the control group as well as to the group of obese adolescents without insulin resistance. At the same time, the expression level of ADM gene did not change significantly in obese adolescents without insulin resistance, but the development of insulin resistance led to down-regulation of this gene expression. In subcutaneous adipose tissue of obese adult men without insulin resistance the level of SLC1A3 gene expression was decreased, although ADM, MEST, and HSPA5 genes - increased. It was also shown that the development of insulin resistance in obese men affected the expression level of ADM and SLCIA3 genes only. Results of this investigation provide evidence that insulin resistance in obese adolescents and adult men is associated with specific changes in the expression of genes, which related to proliferation and development of obesity and insulin resistance as well as to endoplasmic reticulum stress and contribute to the development of obesity complications.

K e y w or d s: obesity, insulin resistance, gene expression, MEST, HSPA5, ADM, blood, adipose tissue.

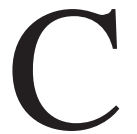

hildren with severe obesity are at greater risk for adult obesity, early atherosclerosis, hypertension, metabolic syndrome, type 2 diabetes, fatty liver disease and premature death [1]. Thus, childhood obesity is a serious and urgent public health problem because the number of children with severe obesity is significantly increased [1]. The development of obesity, as well as its metabolic complications, is associated with dysregulation of numerous intrinsic mechanisms, which control most key metabolic processes, including proliferation, glucose and lipid metabolism as well as insulin sensitivity [2-5]. Furthermore, obesity, as well as meta- bolic syndrome, results from interactions between genes and environmental factors and is associated with changes in gene expressions of the regulatory network in various organs and tissues, but preferentially in adipose tissue [5-8]. Adipose tissue growth is in the center of obesity and tightly associated with glucose and lipid metabolism as well as cell proliferation processes and is controlled by various interconnected regulatory factors and enzymes [9]. At the same time, the blood reflects numerous changes in different organs and tissues in various diseases including obesity $[10,11]$. Special interest deserves the key regulatory factors, which control cell pro-

(C) 2019 Minchenko O. H. et al. This is an open-access article distributed under the terms of the Creative Commons Attribution License, which permits unrestricted use, distribution, and reproduction in any medium, provided the original author and source are credited. 
liferation, glucose and lipid metabolism as well as endoplasmic reticulum stress [2, 4, 8, 12, 13]. Thus, adolescent obesity is associated with increased expression of IRS1, CCN2, IGSEC, RSPO1, IL13RA2, and $R I P K 2$ genes and down-regulated IRS2 and DNAJC15 gene expressions, although with insulin resistance is associated the expression $I R S 1, I R S 2$, DNAJC15, RSPO1, and RIPK2 genes only [13].

Numerous data clearly demonstrate that key regulatory factors, enzymes and receptors including ADM (adrenomedullin), SLC1A3 (solute carrier family 1, member 3: glial high-affinity glutamate transporter), PDGFC (platelet-derived growth factor C), MEST (mesoderm specific transcript) and HSPA5 (heat shock protein family A member 5) represent poly-functional, endoplasmic reticulum stress-dependent proteins, which control variable metabolic pathways and are related to oncogenesis [8, 14-19]. Therefore, adrenomedullin is a potent hypotensive peptide, which controls leptin, endothelin-1, and adiponectin secretion as well as has relation to the development of insulin resistance and metabolic syndrome [20-23]. Moreover, the increase in leptin and the decrease in adiponectin by ADM in the epididymal fat may have opposite effects on metabolism [22]. Leptin is an important regulator of adipose tissue growth and participates in various signaling pathways including cell proliferation. It is interesting to note that $\mathrm{ADM}$ is increased in tumors, promotes metastasis and has relation to oncogenesis $[14,15,23]$. Therefore, there is data that ADM and erythropoietin receptor may serve as new regulatory factors involved in angiogenesis of hepatocellular carcinoma [24].

SLC1A3 (solute carrier family 1 member 3 ) is a mitochondrial protein EAAT1 (excitatory amino acid transporters 1), which also known as glial highaffinity glutamate transporter (GLAST1), controls transport of L-glutamate and also L- and D-aspartate and is essential for terminating the postsynaptic action of glutamate by rapidly removing released glutamate from the synaptic cleft $[16,25,26]$. It is also localized in adipocytes and insulin, which coordinates the catabolism of nutrients by protein phosphorylation, controls the phosphorylation of the Glu/Asp transporter SLC1A3/EAAT1 in these cells [26]. Recently was shown that a high-fat diet reduces the hippocampal content level of lactate which is correlated with the expression of glial glutamate transporters [25]. Platelet-derived growth factor-C (PDGF-C), also known as VEGFE (vascular endothelial growth factor $\mathrm{E}$ ), has roles in the regulation of many biologi- cal processes including embryonic development, angiogenesis, cell proliferation and differentiation, and contribute to the pathophysiology of some diseases, including cancer [27]. It also plays an important role in angiogenesis and blood vessel development, induces anti-apoptotic effects on macrophages through Akt and Bad phosphorylation, but in the nucleus, PDGFC seems to have additional function [17].

Heat shock protein family A member 5 (HSPA5) is a member of the heat shock protein 70 (HSP70) family and is localized in the lumen of the endoplasmic reticulum. It is involved in the correct folding and assembly of proteins in the endoplasmic reticulum as well as in the degradation of misfolded proteins via its interaction with DNAJC10 [18]. HSPA5 protein is also known as glucose-regulated $78 \mathrm{kDa}$ protein (GRP78) and immunoglobulin heavy chain-binding protein (BiP) as well as endoplasmic reticulum luminal $\mathrm{Ca}(2+)$-binding protein grp78. It is a poly-functional protein, which also presents in a nucleus, mitochondrion and extracellular matrix, participates in the control of various metabolic pathways and plays an important role in endoplasmic reticulum stress, obesity and insulin resistance as well as in adipogenesis and oncogenesis [18, 28-34]. Thus, the endoplasmic reticulum luminal co-chaperone ERdj4/DNAJB9 is a selective IRE1 repressor that promotes a complex between the luminal HSP70 $\mathrm{BiP}$ and the luminal stress-sensing domain of IRE1 [18]. Moreover, recently was shown that p53 targets $\mathrm{BiP}$ to promote apoptosis during severe endoplasmic reticulum stress and that cell surface BiP/GRP78 facilitates hepatoma cells proliferation and migration by activating IGF-IR [30, 35].

Next poly-functional gene, which has relation to obesity, insulin resistance, and cell proliferation, is MEST (mesoderm specific transcript) [36-38]. Thus, epigenetic malprogramming of MEST may contribute to obesity predisposition throughout life [36]. It is interesting to note that females are more protected from age-related metabolic disturbances, such as insulin resistance, hepatic lipid deposition, and white adipose tissue inflammation compared to males. This may be related to their greater capacity for white adipose tissue expansion-reflected by a greater MEST/LEPTIN mRNA ratio and to their ability to maintain adiponectin levels and preserve leptin sensitivity with aging [37]. MEST is a stress responsible gene and strongly up-regulated in glioma cells after inhibition of endoplasmic reticulum stress mediated by IRE1 signaling [39]. Moreover, the neuroanatomical and phenotypical consequences 
detected upon the loss of MEST, resemble the loss of substantia nigra neurons and loss of movement control as seen in Parkinson's disease, suggesting that the MEST mouse model may be used as a modelsystem for this disease [40].

Furthermore, ADM, SLC1A3, PDGFC, MEST, and $H S P A 5 / B i P$ genes have relation to obesity and insulin resistance as well as to oncogenesis. Investigation on SNARK knockout mice had shown that obesity and metabolic syndrome in these animals are associated with azoxymethane-induced colorectal tumorigenesis [41].

Many different factors affecting homeostasis have been shown to induce a complex of intracellular signaling events in the endoplasmic reticulum, which is known as the unfolded protein response/endoplasmic reticulum stress [8, 9, 42, 43]. Activation of the endoplasmic reticulum stress sensors leads to transcriptional reprogramming of the cells [43, 44]. The endoplasmic reticulum stress is recognized as an important determinant of obesity and type 2 diabetes and contributes to the expression profile of many regulatory genes resulting in proliferation, apoptosis, and peripheral insulin resistance $[8,9,42$, 43], although detailed molecular mechanisms cannot be ruled out.

The main goal of this study was to clarify the role of the expression of a subset of genes, encoding for important cell proliferation factors, in the blood of obese adolescents and subcutaneous adipose tissue of obese adult men for evaluation of its possible significance to the development of obesity and insulin resistance.

\section{Materials and Methods}

Patient's Clinical Characteristics. The 21 male adolescents participate in this study. They were di- vided into three equal groups (7 subjects in each group): one group of relative healthy individuals without signs of obesity as control and two groups of obese patients: with or without insulin resistance. All participants gave written informed consent and the studies were approved by the local research ethics committees of the Institute of Children and Adolescent Health Care of the National Academy of Medical Science of Ukraine.

Clinical characteristics of the study participants are shown in Table.

The relative healthy (control) participants were individuals with a mean age $14.20 \pm 0.58$ years and a mean body mass index (BMI) $18.80 \pm 0.17 \mathrm{~kg} / \mathrm{m}^{2}$. The obese participants with normal insulin sensitivity as well as the patients with insulin resistance were individuals with a mean age $(13.80 \pm 0.27$ and $14.5 \pm 0.3$ years, correspondingly) and mean BMI (31.10 \pm 0.36 and $34.30 \pm 1.72 \mathrm{~kg} / \mathrm{m}^{2}$, correspondingly). Thus, BMI, which is a main criterion of obesity, in these last two groups of patients was significantly higher (+65 and $+82 \%$, correspondingly; $P<0.01$ in both cases) as compared to control individuals (Table).

Moreover, no significant changes were found in insulin resistance index (HOMA) in obese individuals as compared to relative healthy control group, but in obese patients with impaired insulin sensitivity, versus control boys as well as obese subjects with normal insulin sensitivity the insulin resistance index is significantly increased (3.6- and 3.2-fold, correspondingly; $P<0.001$ in both cases) (Table). Similar results were observed in the fasting insulin levels: no significant changes in obese individuals and strong increase in obese adolescents with insulin resistance (3.3- and 3-fold, correspondingly; $P<0.001$ ) as compared to control group. At the same time, both

\section{Clinical characteristics of the study participants}

\begin{tabular}{lccc}
\hline \multicolumn{1}{c|}{ Variable } & Control & Obesity & Obesity + IR \\
\hline Age at visit (years) & $14.2 \pm 0.58$ & $13.8 \pm 0.27$ & $14.5 \pm 0.3$ \\
Body mass index $(\mathrm{BMI})\left(\mathrm{kg} / \mathrm{m}^{2}\right)$ & $18.8 \pm 0.17$ & $31.1 \pm 0.36^{*}$ & $34.3 \pm 1.72^{*}$ \\
Insulin resistance index $(\mathrm{HOMA})$ & $2.38 \pm 0.13$ & $2.63 \pm 0.22$ & $8.51 \pm 0.99 * \wedge$ \\
Fasting insulin $(\mu \mathrm{IU} / \mathrm{ml})$ & $12.8 \pm 0.69$ & $14.3 \pm 0.95$ & $42.5 \pm 4.69 * \wedge$ \\
Fasting glucose $(\mathrm{mmol} / \mathrm{l})$ & $4.07 \pm 0.18$ & $4.3 \pm 0.18$ & $4.6 \pm 0.18$ \\
2h oral glucose tolerance test & & & \\
$($ OGTT) glucose $(\mathrm{mmol} / \mathrm{l})$ & $4.19 \pm 0.12$ & $4.74 \pm 0.22$ & $5.41 \pm 0.25^{*}$ \\
\hline
\end{tabular}

Data are means \pm SEM; IR - insulin resistance; $n=7 ; * P<0.05$ versus control group; $\wedge P<0.05$ versus obese group 
obesity and obesity with insulin resistance did not change the level of fasting glucose significantly, since $2 \mathrm{~h}$ oral glucose tolerance test (OGTT) was significantly higher $(+29 \%$, correspondingly; $P<0.05)$, but only in the group of obese adolescents with insulin resistance as compared to control individuals (Table). The 18 adult males also participated in the study. They were divided into three equal groups: 6 lean healthy controls, 6 obese with normal glucose tolerance, and 6 obese with impaired glucose tolerance and insulin resistance. All participants gave written informed consent and the studies were approved by the local research ethics committees of the Institute of Experimental Endocrinology Slovak Academy of Sciences. Examination of patients and obtaining of biological material (subcutaneous adipose tissue by biopsy) was conducted in the Institute of Experimental Endocrinology of the Slovak Academy of Sciences in compliance with all bioethical requirements under the supervision of Institute's director, Prof. I. Klimes as part of the Lipidomic Net program. Clinical characteristics of the study participants are described previously [45].

$R N A$ isolation. Trisol reagent (Invitrogen, USA) was used for RNA extraction from the blood of healthy adolescents (without obesity) as control and obese individuals with or without insulin resistance as described previously [13]. RNA from subcutaneous adipose tissue samples was extracted using RNasy Lipid Tissue Mini Kit (QIAGEN, Germany) according to the manufacturer's protocol. The RNA pellets were washed with $75 \%$ ethanol and dissolved in nuclease-free water. For additional purification, RNA samples were re-precipitated with 95\% ethanol and re-dissolved in nuclease-free water. RNA concentration and spectral characteristics were measured using NanoDrop Spectrophotometer.

Reverse transcription and quantitative $P C R$ analysis. Thermo Scientific Verso cDNA Synthesis Kit was used for reverse transcription. The expression level of ADM, SLC1A3, PDGFC, MEST, HSPA5, and $A C T B$ genes were measured in RNA samples from blood by a real-time quantitative polymerase chain reaction of complementary DNA (cDNA). The "QuantStudio 5 Real-Time PCR System" (Applied Biosystems), Absolute QPCR SYBRGreen Mix (Thermo Scientific, UK) and the pair of primers specific for each studied gene (Sigma/Aldrich, USA) were used for the quantitative polymerase chain reaction.

The amplification of adrenomedullin (ADM) cDNA was performed using forward primer (5'-
AGTGGGACGTCTGAGACTTT-3') and reverse primer (5'-CACGACTCAGAGCCCACTTA-3'). These oligonucleotides correspond to sequences 80 99 and 280-261 of human ADM cDNA (GenBank accession number NM_001124). The size of the amplified fragment is $201 \mathrm{bp}$. For amplification of the solute carrier family 1 (glial high-affinity glutamate transporter), member 3 (SLC1A3) cDNA we used following primers: forward 5'-CCATTCCCCACTCCTCCTTT- $3^{\prime}$ and reverse 5'-CCACAGAAAGCCAAACCTCC $-3^{\prime}$. The nucleotide sequences of these primers correspond to sequences 175-194 and 423-404 of human SLC1A3 cDNA (GenBank accession number NM_004172). The size of the amplified fragment is $249 \mathrm{bp}$. The amplification of cDNA of the platelet-derived growth factor C (PDGFC), also known as vascular endothelial growth factor E (VEGFE), was performed using forward primer $\left(5^{\prime}-\right.$ CTCCTGGTTAAACGCTGTGG-3') and reverse primer (5'-TATCCTCCTGTGCTCCCTCT-3'). These oligonucleotides correspond to sequences 1314-1333 and 1528-1509 of human PDGFC cDNA (GenBank accession number NM_001272075). The size of the amplified fragment is $215 \mathrm{bp}$. For amplification of the MEST (mesoderm specific transcript) cDNA we used following primers: forward 5'-TTGGCTTCAGTGACAAACCG-3' and reverse 5'-GACAGCACACCTCCATCTT-3'. The nucleotide sequences of these primers correspond to sequences 576-595 and 859-840 of human MEST cDNA (GenBank accession number NM_002402). The size of the amplified fragment is $284 \mathrm{bp}$. The amplification of the heat shock protein family A (Hsp70) member 5 (HSPA5) cDNA, also known as GRP78 (glucose-regulated protein, 78kDa) and immunoglobulin heavy chain-binding protein (BiP), was performed using forward primer $\left(5^{\prime}-\mathrm{GCTG}-\right.$ GCAAGATGAAGCTCTC $-3^{\prime}$ ) and reverse primer (5'-ATCAGACGTTCCCCTTCAGG-3'). These oligonucleotides correspond to sequences 253-272 and 488-469 of human HSPA5 cDNA (GenBank accession number NM_005347). The size of the amplified fragment is $236 \mathrm{bp}$. The amplification of the $\beta$-actin (ACTB) cDNA was performed using forward $-5^{\prime}-$ GGACTTCGAGCAAGAGATGG-3' and reverse 5'-AGCACTGTGTTGGCGTACAG-3' primers. These primers nucleotide sequences correspond to 747-766 and 980-961 of human ACTB cDNA (GenBank accession number NM_001101). The size of the amplified fragment is $234 \mathrm{bp}$. The expression of $\beta$-actin mRNA was used as a control of analyzed RNA quantity. 
The primers were received from Sigma-Aldrich (St. Louis, MO, USA). The quality of amplification products was analyzed by melting curves and by electrophoresis using 2\% agarose gel. An analysis of quantitative PCR was performed using special computer program "Differential Expression Calculator". The values of ADM, SLC1A3, PDGFC, MEST, and HSPA5 mRNA expressions were normalized to the expression of beta-actin mRNA and represented as percent of control 1 (100\%).

Statistical analysis. All values are expressed as mean \pm SEM from triplicate measurements performed in 6 (for adipose tissue) and 7 (for blood) independent experiments. Statistical analysis was performed according to Student's t-test using Excel program as described previously [39].

\section{Results and Discussion}

We analyzed the expression of a subset of genes encoding important regulatory factors such as HSPA5, MEST, SLC1A3, PDGFC, and ADM, which are associated with cell proliferation and endoplasmic reticulum stress, in blood and subcutaneous adipose tissue of obese individuals with and without in- sulin resistance using quantitative polymerase chain reaction. As shown in Fig. 1, the expression level of $A D M$ gene in the blood of obese adolescents without signs of insulin resistance did not change significantly as compared to the control group. At the same time, in obese adolescents with insulin resistance the expression level of this gene in the blood is significantly down-regulated $(-40 \% ; P<0.01)$ as compared to control group and similar changes was observed in $A D M$ gene expression in this group of obese individuals with insulin resistance as compared to the group of obese adolescents without insulin resistance (-39\%; $P<0.01)$ (Fig. 1). Investigation of the level of this gene expression in subcutaneous adipose tissue of obese men with and without insulin resistance shown that in both groups of obese individuals the expression level of $A D M$ gene is up-regulated: $+72 \%$ and $+44 \%$ in obese men without signs of insulin resistance and with insulin resistance, correspondingly, $(P<0.01$ in both cases) and that development of insulin resistance slightly but statistically significant decreased $(-16 \% ; P<0.05)$ the level of this gene expression (Fig. 1).

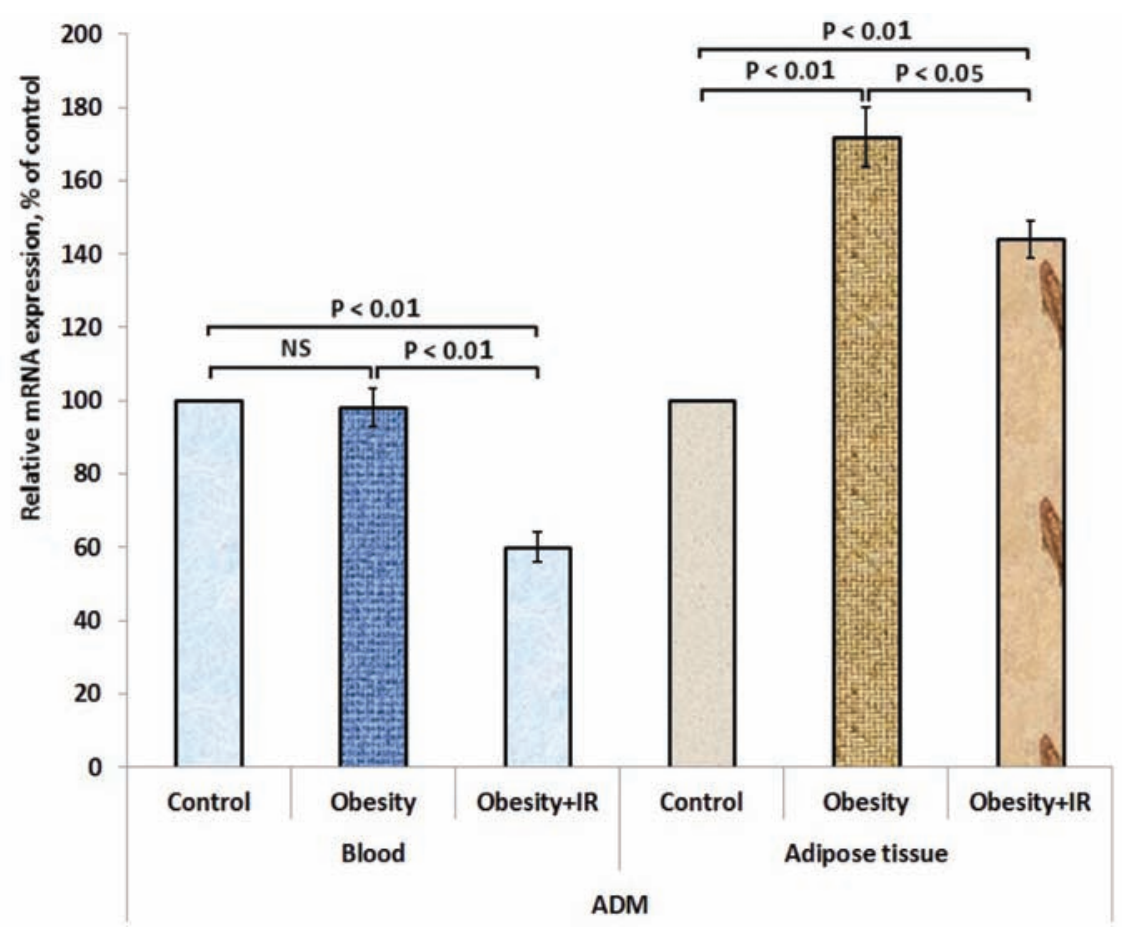

Fig. 1. Adrenomedullin (ADM) mRNA expression in the blood and subcutaneous adipose tissue of obese individuals without signs of insulin resistance (Obesity) and obese patients with insulin resistance (Obesity + $I R)$ as well as in control groups adolescents and men (Control). The values of this mRNA expression were normalized to the expression of $\beta$-actin $m R N A$, expressed as mean $\pm S E M$ and represented as a percent of control (100\%); $n=6-7$ 
Next, we investigated the expression of glial high-affinity glutamate transporter SLC1A3 (member 3 of solute carrier family 1) at mRNA level in the blood of obese adolescents and subcutaneous adipose tissue of obese men with and without insulin resistance. As shown in Fig. 2, the expression level of this mRNA increases in the group of obese individuals without signs of insulin resistance $(+21 \%$; $P<0.05$ ) as compared to the control group of adolescents. At the same time, in obese adolescents with insulin resistance the expression level of SLC1A3 gene in the blood is significantly down-regulated $(-17 \% ; P<0.05)$ as compared to control group and $-31 \%(P<0.01)$ as compared to the group of obese individuals without insulin resistance (Fig. 2). It was also shown that in subcutaneous adipose tissue of obese men without signs of insulin resistance the expression level of SLC1A3 gene is decreased (-14\%; $P<0.05$ ) as compared to control group and that in obese individuals with impaired sensitivity to insulin the changes in this gene expression were more significant $(-26 \% ; P<0.05)$ as compared to control group (Fig. 2).
We also found that in obese adolescents without signs of insulin resistance the expression of MEST gene is up-regulated in the blood $(+44 \% ; P<0.01)$ as compared to relative healthy control group (Fig. 3). Furthermore, development of insulin resistance in obese adolescents leads to down-regulation of this gene expression $(-28 \% ; P<0.01)$ as compared to the group of obese adolescents without signs of insulin resistance (Fig. 3). Similar changes in this gene expression we observed in subcutaneous adipose tissue of obese men without signs of insulin resistance: $+42 \%(P<0.01)$ as compared to control group (Fig. 3). Moreover, it was shown that in subcutaneous adipose tissue of the group of obese individuals with impaired sensitivity to insulin the expression of MEST gene is also up-regulated (+35\%; $P<0.01)$ as compared to control group and that between two these groups of obese men no significant changes were found (Fig. 3).

As shown in Fig. 4, the expression level of $P D G F C$ gene is slightly but statistically significant increased $(+12 \% ; P<0.05)$ in obese adolescents without signs of insulin resistance as compared to

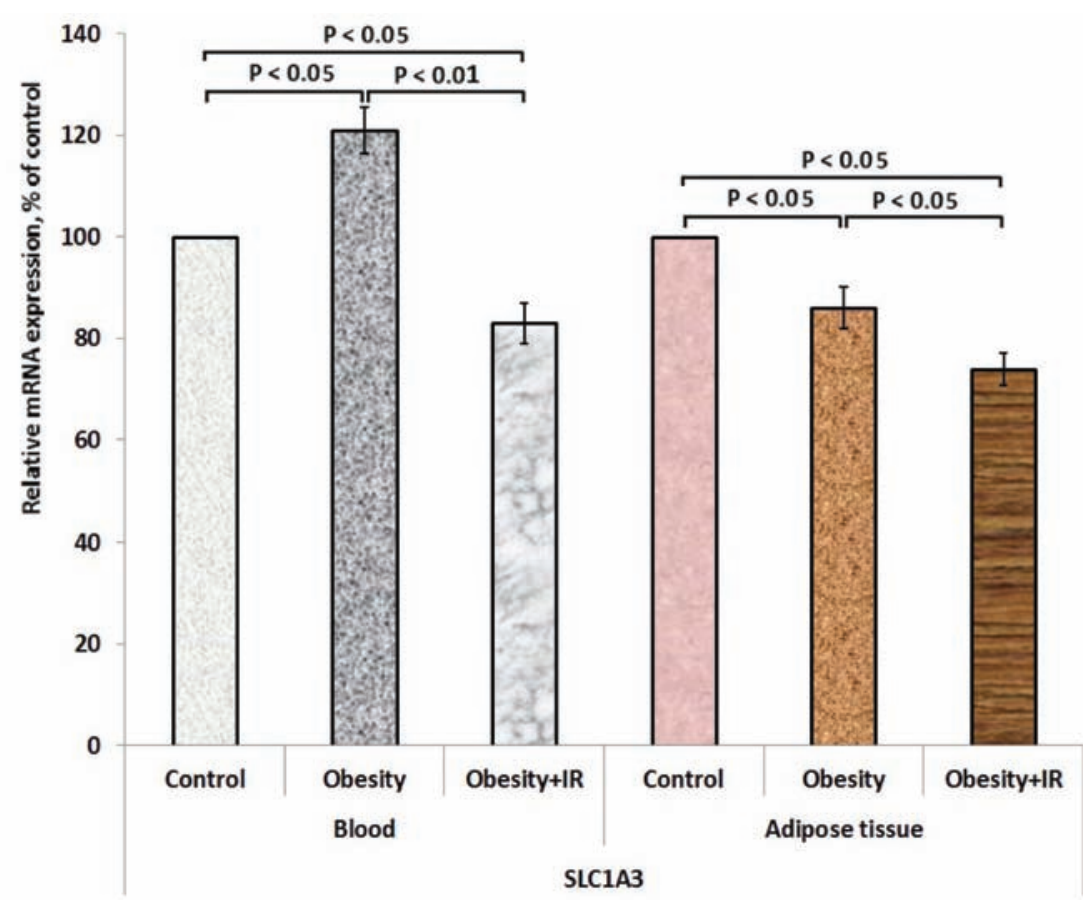

Fig. 2. Solute carrier family 1 (glial high affinity glutamate transporter), member 3 (SLC1A3) mRNA expression in the blood and subcutaneous adipose tissue of obese individuals without signs of insulin resistance (Obesity) and obese patients with insulin resistance (Obesity $+I R)$ as well as in control groups adolescents and men (Control). The values of this $m R N A$ expression were normalized to the expression of $\beta$-actin $m R N A$, expressed as mean \pm SEM and represented as a percent of control (100\%); $n=6-7$ 


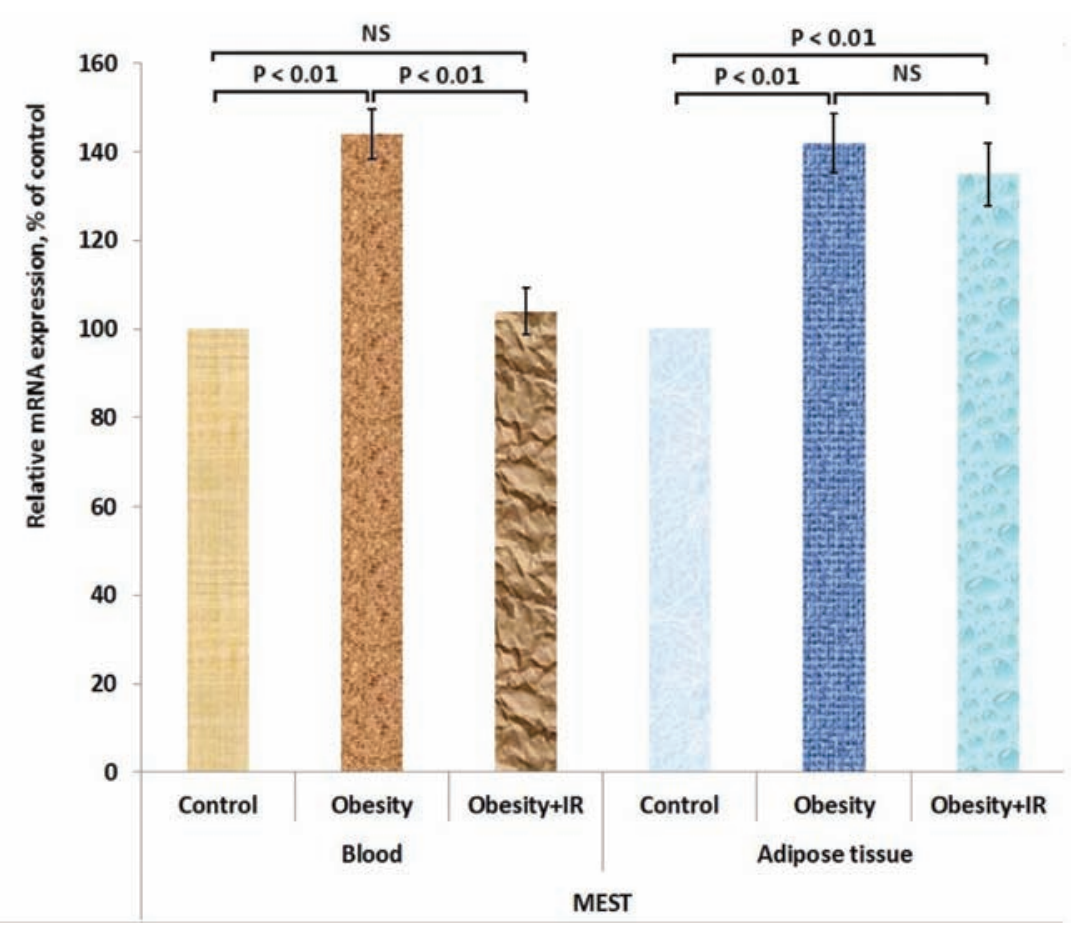

Fig. 3. Mesoderm specific transcript (MEST) mRNA expression in the blood and subcutaneous adipose tissue of obese individuals without insulin resistance (Obesity) and obese patients with insulin resistance (Obesity $+I R)$ as well as in control groups adolescents and men (Control). The values of this $m R N A$ expression were normalized to the expression of $\beta$-actin $m R N A$, expressed as mean $\pm S E M$ and represented as a percent of control (100\%); $n=6-7$

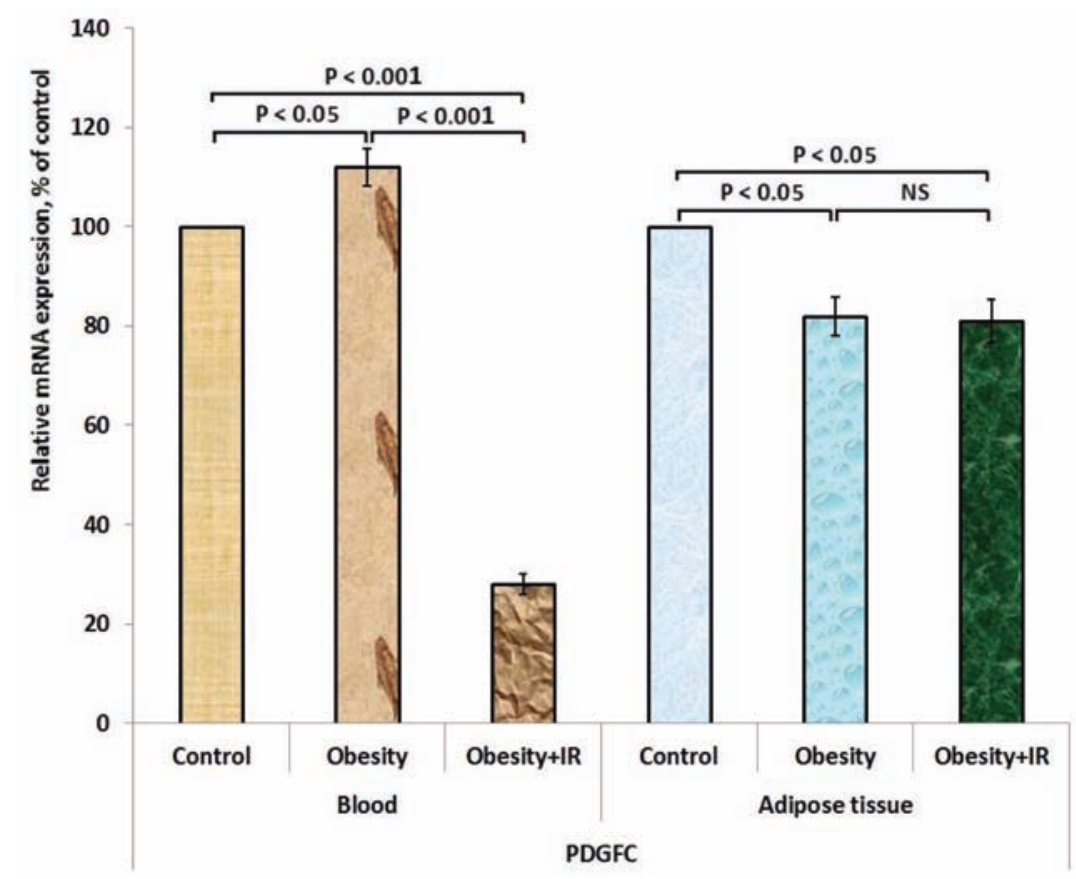

Fig. 4. Platelet-derived growth factor C (PDGFC) $m R N A$ expression in the blood of obese adolescents without signs of insulin resistance (Obesity) and obese patients with insulin resistance (Obesity $+I R)$ as well as in control group of adolescents and men (Control). The values of this $m R N A$ expression were normalized to the expression of $\beta$-actin $m R N A$, expressed as mean \pm SEM and represented as a percent of control $(100 \%) ; n=7$ 
the control group. However, the strong down-regulation in the expression level of this gene is observed in the blood of obese individuals with insulin resistance as compared to relative healthy control group (-72\%; $P<0.001)$ as well as the group of obese adolescents without insulin resistance $(-75 \%$; $P<0.001)$.

Next, we investigated the expression level of HSPA5/BiP mRNA in the blood of obese adolescents and subcutaneous adipose tissue of obese men with and without insulin resistance. As shown in Fig. 5, the expression level of HSPA5 mRNA significantly increases in the group of obese adolescents without signs of insulin resistance $(+71 \%$; $P<0.001)$ as compared to control group of adolescents. Similar changes in this gene expression were observed in subcutaneous adipose tissue of obese adult individuals with impaired sensitivity to insulin: $+58 \%(P<0.01)$ as compared to the control group (Fig. 5). No significant changes were observed in the expression level of HSPA5/BiP mRNA in subcutaneous adipose tissue of obese individuals between two obese groups: without signs of insulin resistance and with impaired sensitivity to insulin (Fig. 5).
Therefore, development of obesity in adolescents and adult men leads to significant changes in the expression level of genes encoding important regulatory proteins resulting in peripheral insulin resistance, proliferation, apoptosis, and oncogenesis [14, 15, 17, 18, 21, 22, 24-27, 29, 30, 32-36].

Results of this investigation demonstrated that obesity changes the expression level of genes encoding important poly-functional regulatory factors, enzymes and receptors such as adrenomedullin (ADM), mesoderm specific transcript (MEST), glial high-affinity glutamate transporter (SLC1A3), platelet-derived growth factor C (PDGFC), and heat shock protein family A member 5 (HSPA5), which represent endoplasmic reticulum stress-dependent proteins, control variable metabolic pathways and are related to obesity, insulin resistance, and oncogenesis in the blood of adolescents and subcutaneous adipose tissue of adult men [8, 14-20, 24-29, 31, 33]. These results are summarized in Fig. 6 and 7. Thus, the expression level of $A D M$ gene is strongly increased in subcutaneous adipose tissue of obese adult men but did not change significantly in the

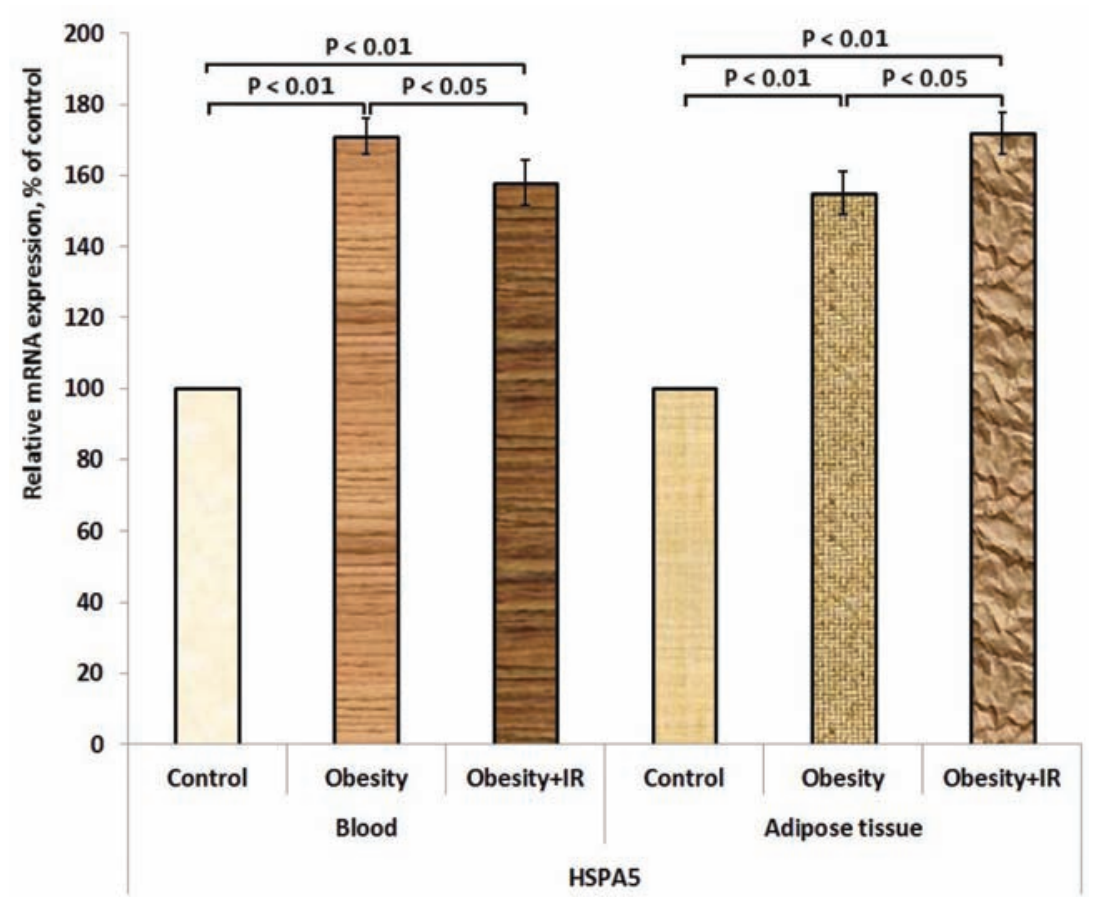

Fig. 5. Heat shock protein A5 (HSPA5), also known as GRP78 (glucose-regulated protein, 78kDa) and immunoglobulin heavy chain-binding protein (BiP), mRNA expression in the blood and subcutaneous adipose tissue of obese individuals without signs of insulin resistance (Obesity) and obese patients with insulin resistance $($ Obesity $+I R)$ as well as in control groups adolescents and men (Control). The values of this $m R N A$ expression were normalized to the expression of $\beta$-actin $m R N A$, expressed as mean $\pm S E M$ and represented as a percent of control (100\%); $n=6-7$ 


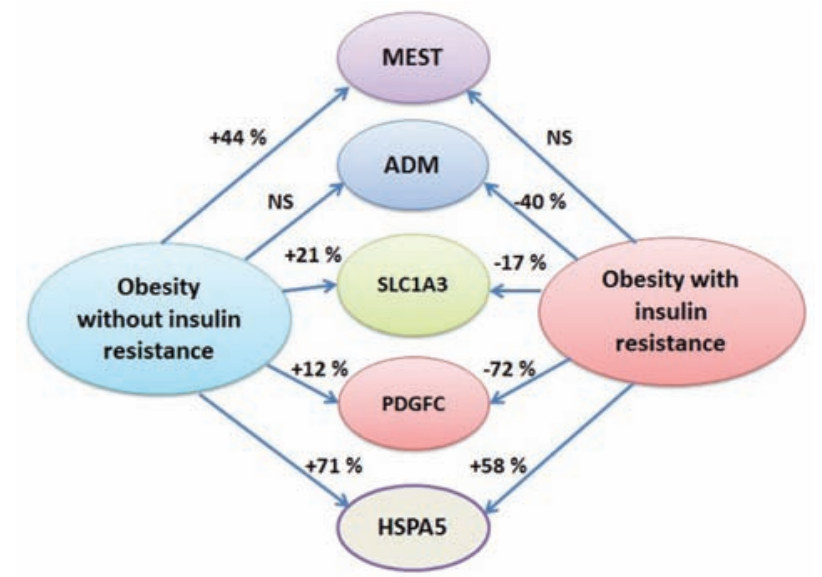

Fig. 6. Schematic demonstration of MEST, ADM, SLC1A3, PDGFC, and HSPA5 genes expression profile in the blood of obese adolescences without signs of insulin resistance and with resistance to insulin as compared to control group; NS - no significant changes

blood of obese adolescent individuals without signs of insulin resistance. It is possible that these results reflect tissue-specific changes meanwhile there is data that most obesity associated changes in gene expressions of the regulatory network are preferentially observed in adipose tissue because adipose tissue growth is in a center of obesity [5-8]. At the same time, the blood reflects numerous changes in different tissues and organs in various diseases including obesity $[10,11]$. Taking into account the nature of ADM functions [15, 20, 21, 23, 24], we suggest, that obesity-mediated up-regulation of its expression in subcutaneous adipose tissue may indicate the possibility of the development obesity complications, including insulin resistance and oncogenesis.

Obtained data also show that obesity increases the expression of MEST gene both in subcutaneous adipose tissue and blood and that such up-regulation could contribute to obesity, insulin resistance, and cell proliferation [36-38]. There is data that MEST participates in the control of leptin level and preserves leptin sensitivity [37]. It is noteworthy, that mesoderm specific transcript gene is an endoplasmic reticulum stress responsible gene and strongly up-regulated in glioma cells after inhibition of endoplasmic reticulum stress mediated by IRE1 signaling [39].

It is possible that changes in the expression of glial high-affinity glutamate transporter SLC1A3/ GLAST1/EAAT1, which we observed in childhood

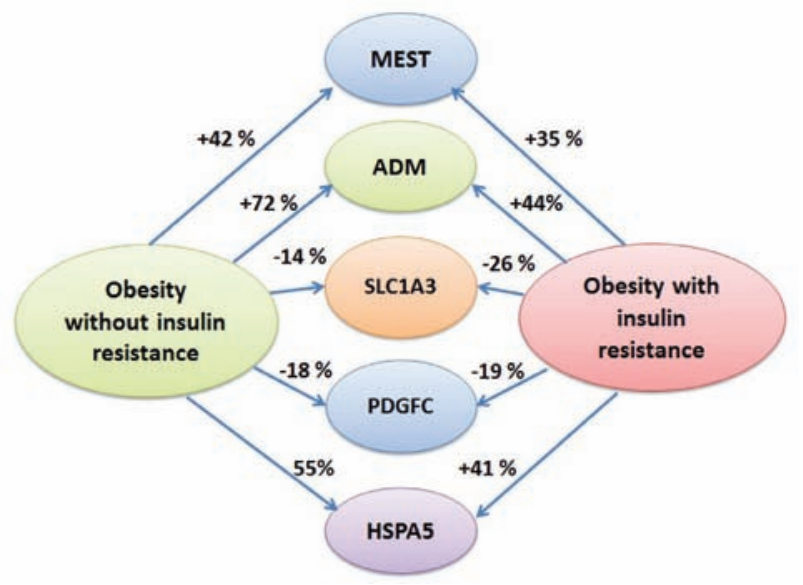

Fig. 7. Schematic demonstration of MEST, ADM, SLC1A3, and HSPA5 genes expression profile in subcutaneous adipose tissue of obese adult men without signs of insulin resistance and with resistance to insulin as compared to control group

obesity and adult men obesity with and without insulin resistance, can also contribute to the numerous intrinsic mechanisms of glucose and lipid metabolism dysregulation, because activity of this protein is controlled by insulin, it also localizes in adipocytes and participates in endoplasmic reticulum stress, an important factor of insulin resistance and obesity $[16,25,26]$. Recently was shown that a high-fat diet reduces the expression of glial glutamate transporters which is correlated with the level of lactate in the hippocampus [25]. It is possible that the expression of SLC1A3 is also controlled by insulin because our results demonstrate significant down-regulation of this gene expression in the blood and adipose tissue of patients with insulin resistance. In this study we have shown that obesity in adolescents and adult men is associated with significant changes in the expression of platelet-derived growth factor-C (PDGFC), also known as VEGFE (vascular endothelial growth factor $\mathrm{E}$ ), which has roles in the regulation of many biological processes including angiogenesis, cell proliferation and differentiation, has some additional functions in the nucleus, and contribute to the pathophysiology of some diseases, including cancer $[17,27]$.

Similar, but more prominent changes were shown for HSPA5 gene in the blood of obese adolescents as well as in subcutaneous adipose tissue of obese adult men in both cases: without signs of insulin resistance and with resistance to insulin as compared to control groups. It is possible that 
HSPA5 contributes to the development of obesity and its complications, because it is a poly-functional protein, which participates in the control of various metabolic pathways and plays an important role in endoplasmic reticulum stress, adipogenesis, obesity, and insulin resistance as well as in oncogenesis [18, 29-33, 35]. Taking into account the nature of HSPA5 function, we suggest that most obesity-associated complications are associated with endoplasmic reticulum stress signaling pathways. There is data that obesity-mediated inflammation is a major cause of insulin resistance and that mice with macrophageselective ablation of HSPA5 are protected from skeletal muscle insulin resistance without changes in obesity compared with wild-type mice after 9 weeks of a high-fat diet [46]. Furthermore, peripheral insulin resistance associated with gestational diabetes mellitus is associated with upregulation of endoplasmic reticulum stress proteins HSPA5/GRP78 and XBP-1s. It is interesting to note that endoplasmic reticulum stress may play an important role for resistin impairment of vascular insulin signaling and insulin action in obesity through up-regulation of HSPA5/ GRP78 [48].

It is possible that identification of real mechanisms of metabolic abnormalities in obesity as well as its complications at molecular and cellular levels helps to better understanding why obesity develops and why only a part of the obese individuals develops secondary metabolic disorders. However, a detailed molecular mechanism of the involvement of different genes of the regulatory network in the development of obesity and its complications are not clear yet and remains to be determined.

This work was partially supported by the $7^{\text {th }}$ Framework Program of European Commission "LipidomicNet" entitled as "Lipid droplets as dynamic organelles of fat deposition and release: translational research towards human disease" and by the National Academy of Sciences of Ukraine (grants \#0111U002234, 2011-2015 and \#0112U002624, 20122016).

Conflict of interest. Authors have completed the Unified Conflicts of Interest form at http:// ukrbiochemjournal.org/wp-content/uploads/2018/12/ coi_disclosure.pdf and declare no conflict of interest.

\section{РЕЗИСТЕНТНІСТЬ ДО ІНСУЛІНУ \\ В ПІДЛІТКІВ ТА ДОРОСЛИХ \\ ЧОЛОВІКІВ 3 ОЖИРІННЯМ \\ МОДИФІКУС ЕКСПРЕСІЮ ГЕНІВ, ЩО МАЮТЬ ВІДНОШЕННЯ ДО ПРОЛІФЕРАЦІЇ}

\author{
О. Г. Мінченко ${ }^{1 凶}$, Ю. М. Вілецька ${ }^{1}$, \\ Д. О. Мінченко ${ }^{1,2}$, В. В. Давидов \\ ${ }^{1}$ Інститут біохімії ім. О. В. Палладіна \\ НАН України, Київ; \\ 凶e-mail: ominchenko@yahoo.com; \\ ${ }^{2}$ Національний медичний університет \\ ім. О. О. Богомольця, Київ, Україна; \\ 3Д3 «Інститут охорони здоров'я дітей та \\ підлітків НАМН України», Харків
}

Вивчено експресію генів HSPA5, MEST, SLC1A3, PDGFC та ADM у крові і підшкірній жировій тканині підлітків та дорослих чоловіків 3 ожирінням за умов наявності або відсутності резистентності до інсуліну. Встановлено, що в крові підлітків з ожирінням без ознак резистентності до інсуліну рівень експресії генів SLC1A3, HSPA5, MEST та PDGFC істотно збільшувався, але розвиток резистентності до інсуліну призводив до зниження рівня експресії цих генів за винятком гена HSPA5 у разі порівняння як 3 контрольною групою, так і з групою підлітків 3 ожирінням без ознак резистентності до інсуліну. В той самий час рівень експресії гена $A D M$ в підлітків $з$ ожирінням без ознак резистентності до інсуліну істотно не змінювався, а розвиток резистентності до інсуліну призводив до зниження рівня експресії цього гена. У підшкірній жировій тканині дорослих чоловіків з ожирінням за умов відсутності резистентності до інсуліну рівень експресії гена SLC1A3 знижувався, а генів $A D M$, MEST і HSPA5 - збільшувався. Також було показано, що розвиток резистентності до інсуліну в чоловіків з ожирінням змінював рівень експресії лише генів $A D M$ та $S L C 1 A 3$. Результати дослідження продемонстрували, що резистентність до інсуліну в підлітків та дорослих чоловіків 3 ожирінням асоціюється із специфічними змінами в експресії генів, які пов'язані з проліферацією і розвитком ожиріння та резистентності до інсуліну, а також зі стресом ендоплазматичного ретикулума, і зумовлюють розвиток ускладнень ожиріння. 
Ключов і слова: ожиріння, резистентність до інсуліну, експресія генів, MEST, HSPA5, ADM, кров, жирова тканина.

\section{References}

1. Bass R, Eneli I. Severe childhood obesity: an under-recognised and growing health problem. Postgrad Med J. 2015; 91(1081): 639-645.

2. Ruderman NB1, Carling D, Prentki M, Cacicedo JM. AMPK, insulin resistance, and the metabolic syndrome. J Clin Invest. 2013; 123(7): 2764-2772.

3. Tam J, Szanda G, Drori A, Liu Z, Cinar R, Kashiwaya Y, Reitman ML, Kunos G. Peripheral cannabinoid-1 receptor blockade restores hypothalamic leptin signaling. Mol Metab. 2017; 6(10): 1113-1125.

4. Ghoshal S, Stevens JR, Billon C, Girardet C, Sitaula S, Leon AS, Rao DC, Skinner JS, Rankinen T, Bouchard C, Nuñez MV, Stanhope KL, Howatt DA, Daugherty A, Zhang J, Schuelke M, Weiss EP, Coffey AR, Bennett BJ, Sethupathy P, Burris TP, Havel PJ, Butler AA. Adropin: An endocrine link between the biological clock and cholesterol homeostasis. Mol Metab. 2018; 8: 51-64.

5. Mao Z, Zhang W. Role of mTOR in glucose and lipid metabolism. Int J Mol Sci. 2018; 19(7). pii: E2043.

6. Shimba S, Ogawa T, Hitosugi S, Ichihashi Y, Nakadaira Y, Kobayashi M, Tezuka M, Kosuge Y, Ishige $\mathrm{K}$, Ito $\mathrm{Y}$, Komiyama $\mathrm{K}$, OkamatsuOgura Y, Kimura K, Saito M. Deficient of a clock gene, brain and muscle Arnt-like protein-1 (BMAL1), induces dyslipidemia and ectopic fat formation. PLoS One. 2011; 6(9): e25231.

7. Wang M, Kaufman RJ. Protein misfolding in the endoplasmic reticulum as a conduit to human disease. Nature. 2016; 529(7586): 326-335.

8. Han J, Kaufman RJ. Measurement of the unfolded protein response to investigate its role in adipogenesis and obesity. Methods Enzymol. 2014; 538: 135-150.

9. Lee J, Ozcan U. Unfolded protein response signaling and metabolic diseases. J Biol Chem. 2014; 289(3): 1203-1211.

10. Ando H, Kumazaki M, Motosugi Y, Ushijima K, Maekawa T, Ishikawa E, Fujimura A. Impairment of peripheral circadian clocks precedes metabolic abnormalities in ob/ob mice. Endocrinology. 2011; 152(4): 1347-1354.
11. Yamaoka M, Maeda N, Nakamura S, Kashine S, Nakagawa Y, Hiuge-Shimizu A, Okita K, Imagawa A, Matsuzawa Y, Matsubara K, Funahashi T, Shimomura I. A pilot investigation of visceral fat adiposity and gene expression profile in peripheral blood cells. PLoS One. 2012; 7(10): e47377.

12. Hassler JR, Scheuner DL, Wang S, Han J, Kodali VK, Li P, Nguyen J, George JS, Davis C, Wu SP, Bai Y, Sartor M, Cavalcoli J, Malhi H, Baudouin G, Zhang Y, Yates JR III, Itkin-Ansari P, Volkmann N, Kaufman RJ. The IRE1 $\alpha /$ XBP1s pathway is essential for the glucose response and protection of $\beta$ cells. PLOS Biol. 2015; 13(10): e1002277.

13. Minchenko DO, Davydov VV, Budreiko OA, Moliavko OS, Kulieshova DK, Tiazhka OV, Minchenko OH. The expression of CCN2, IQSEC, RSPO1, DNAJC15, RIPK2, IL13RA2, IRS1, and IRS2 genes in blood of obese boys with insulin resistance. Fiziol Zh. 2015; 61(1): 10-18.

14. Aggarwal G, Ramachandran V, Javeed N, Arumugam T, Dutta S, Klee GG, Klee EW, Smyrk TC, Bamlet W, Han JJ, Rumie Vittar NB, de Andrade M, Mukhopadhyay D, Petersen GM, Fernandez-Zapico ME, Logsdon CD, Chari ST. Adrenomedullin is up-regulated in patients with pancreatic cancer and causes insulin resistance in $\beta$ cells and mice. Gastroenterology. 2012; 143(6): 1510-1517.

15. Zhou C, Zheng Y, Li L, Zhai W, Li R, Liang Z, Zhao L. Adrenomedullin promotes intrahepatic cholangiocellular carcinoma metastasis and invasion by inducing epithelial-mesenchymal transition. Oncol Rep. 2015; 34(2): 610-616.

16. Lee A, Anderson AR, Beasley SJ, Barnett NL, Poronnik P, Pow DV. A new splice variant of the glutamate-aspartate transporter: cloning and immunolocalization of GLAST1c in rat, pig and human brains. J Chem Neuroanat. 2012; 43(1): 52-63.

17. Son D, Na YR, Hwang ES, Seok SH. Plateletderived growth factor-C (PDGF-C) induces anti-apoptotic effects on macrophages through Akt and Bad phosphorylation. J Biol Chem. 2014; 289(9): 6225-6235.

18. Amin-Wetzel N, Saunders RA, Kamphuis MJ, Rato C, Preissler S, Harding HP, Ron D. A J-Protein Co-chaperone Recruits $\mathrm{BiP}$ to Monomerize IRE1 and Repress the Unfolded Protein Response. Cell. 2017; 171(7): 1625-1637. 
19. Bravo R, Parra V, Gatica D, Rodriguez AE, Torrealba N, Paredes F, Wang ZV, Zorzano A, Hill JA, Jaimovich E, Quest AF, Lavandero S. Endoplasmic reticulum and the unfolded protein response: dynamics and metabolic integration. Int Rev Cell Mol Biol. 2013; 301: 215-290.

20. Zhang SY, Lv Y, Zhang H, Gao S, Wang T, Feng J, Wang Y, Liu G, Xu MJ, Wang X, Jiang C. Adrenomedullin 2 improves early obesityinduced adipose insulin resistance by inhibiting the class II MHC in adipocytes. Diabetes. 2016; 65(8): 2342-2355.

21. Zhang $\mathrm{H}$, Zhang SY, Jiang $\mathrm{C}$, Li Y, Xu G, Xu MJ, Wang X. Intermedin/adrenomedullin 2 polypeptide promotes adipose tissue browning and reduces high-fat diet-induced obesity and insulin resistance in mice. Int $J$ Obes (Lond). 2016; 40(5): 852-860.

22. Liao SB, Wong PF; WSO, Cheung BM, Tang F. Effects of adrenomedullin on tumour necrosis factor alpha, interleukins, endothelin-1, leptin, and adiponectin in the epididymal fat and soleus muscle of the rat. Horm Metab Res. 2013; 45(1): 31-37.

23. Di Liddo R, Bridi D, Gottardi M, De Angeli S, Grandi C, Tasso A, Bertalot T, Martinelli G, Gherlinzoni F, Conconi MT. Adrenomedullin in the growth modulation and differentiation of acute myeloid leukemia cells. Int J Oncol. 2016; 48(4): 1659-1669.

24. Qu Z, Jiang Y, Xu M, Lu MZ, Zhou B, Ding Y. Correlation of adrenomedullin with the erythropoietin receptor and microvessel density in hepatocellular carcinoma. Arch Med Sci. 2015; 11(5): 978-981.

25. Tsai SF, Chen YW, Kuo YM. High-fat diet reduces the hippocampal content level of lactate which is correlated with the expression of glial glutamate transporters. Neurosci Lett. 2018;662:142-146.

26. Krycer JR, Fazakerley DJ, Cater RJ, C Thomas K, Naghiloo S, Burchfield JG, Humphrey SJ, Vandenberg RJ, Ryan RM, James DE. The amino acid transporter, SLC1A3, is plasma membrane-localised in adipocytes and its activity is insensitive to insulin. FEBS Lett. 2017; 591(2): 322-330.

27. Bartoschek M, Pietras K. PDGF family function and prognostic value in tumor biology. Biochem Biophys Res Commun. 2018; 503(2): 984-990.

28. Wang C, Cai L, Liu J, Wang G, Li H, Wang X, $\mathrm{Xu} \mathrm{W}$, Ren $\mathrm{M}$, Feng L, Liu P, Zhang C.
MicroRNA-30a-5p inhibits the growth of renal cell carcinoma by modulating GRP78 expression. Cell Physiol Biochem. 2017; 43(6): 2405-2419.

29. Kang JM, Park S, Kim SJ, Kim H, Lee B, Kim J, Park J, Kim ST, Yang HK, Kim WH, Kim SJ. KIAA1324 suppresses gastric cancer progression by inhibiting the oncoprotein GRP78. Cancer Res. 2015; 75(15): 3087-3097.

30. López I, Tournillon AS, Prado Martins R, Karakostis K, Malbert-Colas L, Nylander K, Fåhraeus R. p53-mediated suppression of BiP triggers BIK-induced apoptosis during prolonged endoplasmic reticulum stress. Cell Death Differ. 2017; 24(10): 1717-1729.

31. Smaldone G, Pirone L, Capolupo A, Vitagliano L, Monti MC, Di Gaetano S, Pedone E. The essential player in adipogenesis GRP78 is a novel KCTD15 interactor. Int J Biol Macromol. 2018; 115: 469-475.

32. Lin C, Wang J, Wang Y, Zhu P, Liu X, Li N, Liu J, Yu L, Wang W. GRP78 Participates in PCA3-regulated prostate cancer progression. Anticancer Res. 2017;37(8):4303-4310.

33. Ogawa H, Kaira K, Takahashi K, Shimizu A, Altan B, Yoshinari D, Asao T, Oyama T. Prognostic role of BiP/GRP78 expression as ER stress in patients with gastric adenocarcinoma. Cancer Biomark. 2017; 20(3): 273-281.

34. Luo J, Xia Y, Luo J, Li J, Zhang C, Zhang H, Ma T, Yang L, Kong L. GRP78 inhibition enhances ATF4-induced cell death by the deubiquitination and stabilization of CHOP in human osteosarcoma. Cancer Lett. 2017; 410: 112-123.

35. Yin Y, Chen C, Chen J, Zhan R, Zhang Q, Xu X, Li D, Li M. Cell surface GRP78 facilitates hepatoma cells proliferation and migration by activating IGF-IR. Cell Signal. 2017; 35: 154162.

36. El Hajj N, Pliushch G, Schneider E, Dittrich M, Müller T, Korenkov M, Aretz M, Zechner U, Lehnen $\mathrm{H}$, Haaf T. Metabolic programming of MEST DNA methylation by intrauterine exposure to gestational diabetes mellitus. Diabetes. 2013; 62(4): 1320-1328.

37. Garcia-Carrizo F, Priego T, Szostaczuk N, Palou A, Picó C. Sexual dimorphism in the ageinduced insulin resistance, liver steatosis, and adipose tissue function in rats. Front Physiol. 2017; 8: 445. 
38. Anunciado-Koza RP, Manuel J, Mynatt RL, Zhang J, Kozak LP, Koza RA. Diet-induced adipose tissue expansion is mitigated in mice with a targeted inactivation of mesoderm specific transcript (Mest). PLoS One. 2017; 12(6): e0179879.

39. Minchenko OH, Tsymbal DO, Minchenko DO, Kubaychuk OO. Hypoxic regulation of MYBL1, MEST, TCF3, TCF8, GTF2B, GTF2F2 and SNAI2 genes expression in U87 glioma cells upon IRE1 inhibition. Ukr Biochem J. 2016; 88(6): 52-62.

40. Mesman S, van Hooft JA, Smidt MP. Mest/ Peg1 Is Essential for the Development and Maintenance of a SNc Neuronal Subset. Front Mol Neurosci. 2017; 9: 166.

41. Tsuchihara K, Ogura T, Fujioka R, Fujii S, Kuga W, Saito M, Ochiya T, Ochiai A, Esumi H. Susceptibility of Snark-deficient mice to azoxymethane-induced colorectal tumorigenesis and the formation of aberrant crypt foci. Cancer Sci. 2008; 99(4): 677-682.

42. Manié SN, Lebeau J, Chevet E. Cellular mechanisms of endoplasmic reticulum stress signaling in health and disease. 3. Orchestrating the unfolded protein response in oncogenesis: an update. Am J Physiol Cell Physiol. 2014; 307(10): C901-C907.

43. Chevet E, Hetz C, Samali A. Endoplasmic reticulum stress-activated cell reprogramming in oncogenesis. Cancer Discov. 2015; 5(6): 586597.

44. Doultsinos D, Avril T, Lhomond S, Dejeans N, Guédat P, Chevet E. Control of the Unfolded Protein Response in Health and Disease. SLAS Discov. 2017; 22(7): 787-800.

45. Minchenko D, Ratushna O, Bashta Y, Herasymenko R, Minchenko O. The expression of TIMP1, TIMP2, VCAN, SPARC, CLEC3B and E2F1 in subcutaneous adipose tissue of obese males and glucose intolerance. CellBio. 2013; 2(2): 45-53.

46. Kim JH, Lee E, Friedline RH, Suk S, Jung DY, Dagdeviren S, Hu X, Inashima K, Noh HL, Kwon JY, Nambu A, Huh JR, Han MS, Davis RJ, Lee AS, Lee KW, Kim JK. Endoplasmic reticulum chaperone GRP78 regulates macrophage function and insulin resistance in diet-induced obesity. FASEB J. 2018; 32(4): 2292-2304.

47. Liong S, Lappas M. Endoplasmic reticulum stress regulates inflammation and insulin resistance in skeletal muscle from pregnant women. Mol Cell Endocrinol. 2016; 425: 11-25.

48. Luo J, Huang L, Wang A, Liu Y, Cai R, Li W, Zhou MS. Resistin-induced endoplasmic reticulum stress contributes to the impairment of insulin signaling in endothelium. Front Pharmacol. 2018; 9: 1226. 